\title{
Traditional use of medicinal plants by elderly
}

\author{
Uso tradicional de plantas medicinais por idosos
}

Alexandre Rocha Alves Pereira' ${ }^{1}$, Ana Paula Machado Velho², Diógenes Aparício Garcia Cortez ${ }^{2}$, Laura Ligiana Dias Szerwieski² ${ }^{2}$ Lucia Elaine Ranieri Cortez ${ }^{2}$

Objective: identify the traditional use of medicinal plants by the elderly. Methods: exploratory and descriptive study conducted in the Intermunicipal Consortium on Health. Three hundred and fifty-one questionnaires were applied to the elderly to survey socio-demographic information and issues related to plants. Results: the use of plants was reported by 78.4\% of the elderly, and these were collected in backyards. The most often cited plants were mint, boldo, fennel, lemongrass and chamomile. Regarding the reason for use, 33.3\% participants said that "it's not harmful to health", $61.8 \%$ usually indicate the use to other people. Most elderly make use of plants in a safe manner, and these are present in the daily lives of these people as a therapeutic method. Conclusion: the elderly make use of medicinal plants as an important therapeutic resource.

Descriptors: Plants, Medicinal; Aged; Health of the Elderly; Nursing.

Objetivo: identificar o uso tradicional de plantas medicinais por idosos. Métodos: estudo exploratóriodescritivo realizado em Consórcio Intermunicipal de Saúde. Foram aplicados 351 questionários aos idosos, contendo informações sociodemográficas e questões relacionadas às plantas. Resultados: foi relatado o uso de plantas por $78,4 \%$ dos idosos, estas adquiridas em quintais. As mais citadas: hortelã, boldo, erva doce, capim limão e camomila. Com relação ao motivo de uso, 33,3\% afirmaram "não fazer mal à saúde", $61,8 \%$ indicavam o uso para outras pessoas. A maioria dos idosos utiliza-se das plantas de forma segura, estando presentes no cotidiano destas pessoas como uma forma terapêutica. Conclusão: os idosos fazem uso das plantas medicinais, como um importante recurso terapêutico.

Descritores: Plantas Medicinais; Idoso; Saúde do Idoso; Enfermagem.

\footnotetext{
${ }^{1}$ Universidade Norte do Paraná. Arapongas, PR, Brazil.
}

${ }^{2}$ Centro Universitário Cesumar. Maringá, PR, Brazil. 


\section{Introduction}

The use of medicinal plants dates back to the earliest times of humanity. There are reports of the use of plants for therapeutic purposes around $2000 \mathrm{BC}$, many plants used at that time are used the same way today. In the Western civilizations, the first records are from $1500 \mathrm{BC}$ in the Egyptian manuscript "Ebers Papyrus" Through which the old world became aware of an Egyptian Pharmacopoeia containing various plant species ${ }^{(1)}$.

Through observation and experimentation, therapeutic properties of certain plants were discovered and propagated as part of popular culture in primitive peoples. In Brazil, the knowledge brought by the Jesuits associated with the knowledge of indigenous people helped in controlling epidemics that afflict them, and this made that a series of native plants started to be used and incorporated into our culture $^{(2)}$.

The use of medicinal plants is an important resource for treatment, cure and prevention of numerous diseases and is often guided by the accumulated body of knowledge arising from the direct relationship between individuals and the environment. Ethnobotany is the science responsible for the study of the relationship between medicinal plants and men; it is as an interdisciplinary science whose complexity and performance involves different areas of knowledge ${ }^{(3)}$.

The guidance to users of medicinal plants is a common practice in many professions, and nursing is one of the most active areas in this context. Long ago the use of herbal and natural therapies has inspired the work of nurses and this fact that led to the recognition of this practice by the Nursing Federal Council under Opinion no 004/95 of the Resolution 197/97 and of the Integrative and Policy on Complementary Practices in Health ${ }^{(4)}$.

It is important to note that the implementation of the National Policy on Integrative and Complementary Practices encourages and predict the research on medicinal plants and seeks to promote, in a safe way, the provision of services within the herbal medicine in public health by qualified health professionals ${ }^{(4)}$.

In Brazil, the use of medicinal plants is common among a significant part of the population. It was found that $80.0 \%$ of the Brazilian population uses, or has already used before, medicinal plants in their daily lives and of this total, most consist of people aged at 60 or older. There are gaps to be filled with regard to the use of medicinal plants, due to contraindications, overdose and/or drug interactions or even the overvaluation of plants and lack of knowledge about toxic effects. Thus, this study is justified because it has become necessary to know how these medicinal plants are used, as it is fact that the Brazilian population has undergone an accelerated aging process in recent decades $^{(5)}$.

Thus, this study aimed to identify the traditional use of medicinal plants by the elderly.

\section{Methods}

Descriptive and exploratory study that relied on the voluntary participation of elderly regularly attending the Intermunicipal Public Consortium on Health of the North of Paraná that has the aim to seek joint solutions to health problems, encompassing 30 municipalities of the Association of Municipalities of the North of Paraná.

The sample size calculation assumed a confidence level of $95.0 \%$, margin of error of $5.0 \%$, and was based on calculations made in the Statdisk software Version 8.4. The sample size was 351 elderly $\geq 60$ years.

The researchers identified the elderly that attend the Intermunicipal Public Consortium on Health of the North of Paraná, made an initial approach explaining the research goals and made an invitation to join. In case of acceptance, the consent form was signed and a semi-structured questionnaire applied to survey demographic information (gender, age, education level, monthly income) and issues related to 
the consumption of medicinal plants (plant part used, way of use and why to make use of it, where the plant is collected and if they indicate the medicinal plants to other people). The research went to in this way until the sample size proposed by statistical calculation was reached.

Elderly who were accompanied by a person who previously advised on case of dementia, unstable clinical situtation, cognitive fluctuations and the level of awareness of the elderly, were excluded from the study.

Data were statistically analyzed with the help of the software Statistica 8.0. Evaluation of means and standard deviations for quantitative variables was performed. As for the qualitative variables, frequency tables were used for percentage, and contingency tables using Chi-square test were used to verify possible significant associations between the variables of interest. The significance level was 5.0\%, that is, associations were considered significant when $\mathrm{p}<0.05$.

The study complied with the formal requirements contained in the national and international regulatory standards for research involving human beings.

\section{Results}

This study shows the prevalence of women in the use of medicinal plants 206 (58.7\%), but there was no statistically significant difference between genders ( $p<0.001 *$ ). As for the level of education, 191 (54.4\%) of the elderly had complete or incomplete elementary school, 68 (19.4\%) were illiterate, 30 (8.5\%) had completed high school and only 8 (2.2\%) had completed higher education. Regarding the monthly income of the respondents, 291 (65.5\%) were retired, of which 208 (59.3\%) earned one minimum wage, and $46(13.1 \%)$ earned two minimum wages (Table 1 ).
Table 1 - Relationship between the use of medicinal plants and sociodemographic data

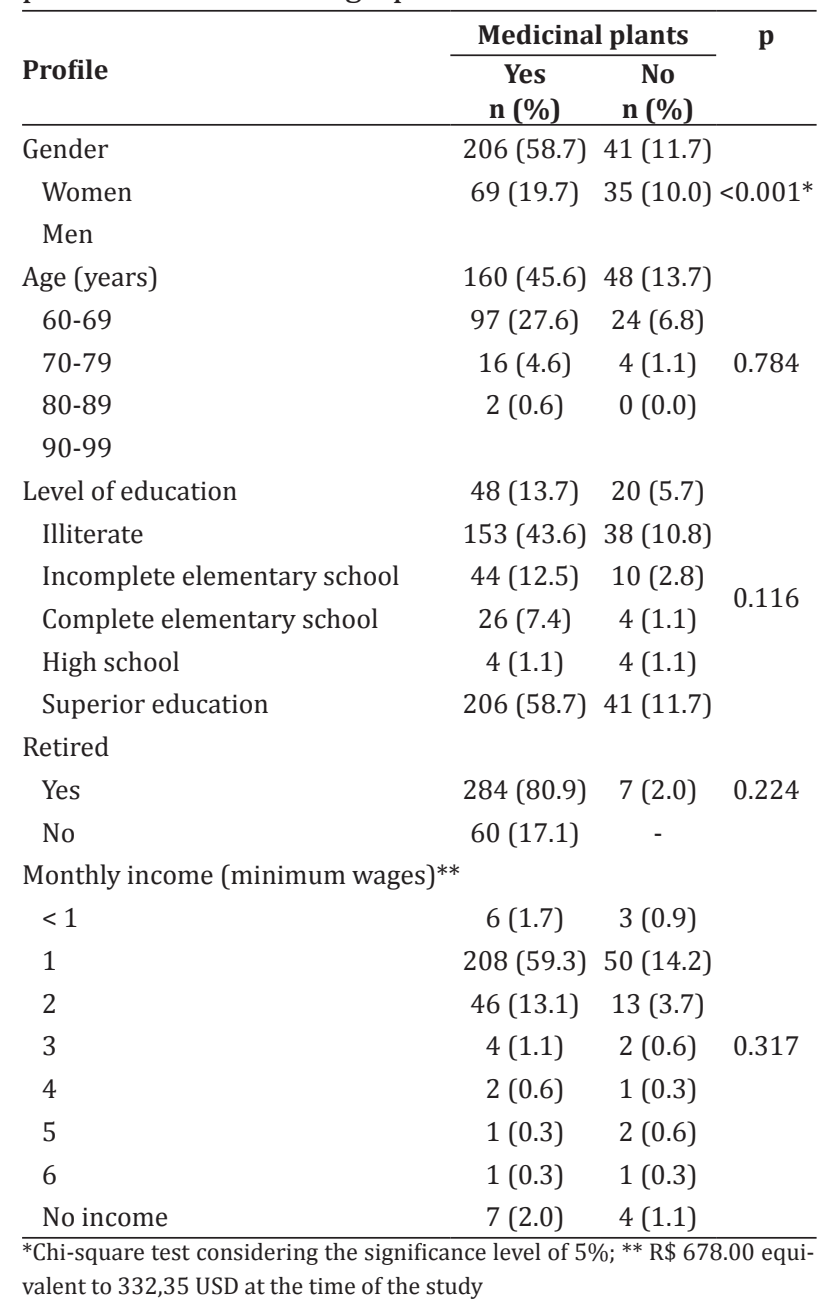

The analysis of the use of these plants by sex showed statistically significant differences between men and women in the use of certain medicinal plants such as arnica, which were cited by 25 women (7.1\%) and 21 men (6.0\%), p=0, 01068, eggplant cited by 29 women (8.3\%) and 5 men (1.4\%), p=0.04493, carqueja cited by 25 women $(7.1 \%)$ and 19 men (5.4\%), $\mathrm{p}=0.03529$, lemongrass cited by 94 women (26.8\%) and 24 men (6.8\%), p=0.00667, and mint cited by 121 women (34.5\%) and 33 men (9.4\%), p = 0.00293 (Table 2). 
Table 2 - Relation between medicinal plants and the gender of respondents

\begin{tabular}{lccc}
\hline \multirow{2}{*}{ Medicinal plants } & \multicolumn{2}{c}{ Gender } & \\
\cline { 2 - 3 } & $\begin{array}{c}\text { Women } \\
\mathbf{n}(\%)\end{array}$ & $\begin{array}{c}\text { Men } \\
\mathbf{n}(\%)\end{array}$ & \\
\hline Arnica & $25(7.1)$ & $21(6.0)$ & $0.010^{*}$ \\
Common Rue & $35(10.0)$ & $17(4.8)$ & 0.600 \\
Boldo & $95(27.1)$ & $51(14.5)$ & 0.066 \\
Melissa & $57(16.2)$ & $20(5.7)$ & 0.426 \\
Carqueja & $25(7.1)$ & $19(5.4)$ & $0.035^{*}$ \\
Chayote & $24(6.8)$ & $4(1.1)$ & 0.063 \\
Elderberry & $16(4.6)$ & $10(2.8)$ & 0.305 \\
Espinheira Santa (Maytenus) & $27(7.7)$ & $8(2.3)$ & 0.355 \\
Guaco & $58(16.5)$ & $23(6.6)$ & 0.781 \\
Seed of anise & $98(27.9)$ & $30(8.5)$ & 0.064 \\
Lemongrass & $94(26.8)$ & $24(6.8)$ & $0.006^{*}$ \\
Mentha & $121(34.5)$ & $33(9.4)$ & $0.002^{*}$ \\
Rosemary & $52(14.8)$ & $18(5.1)$ & 0.422 \\
Chamomile & $85(24.2)$ & $26(7.4)$ & 0.083 \\
Eggplant & $29(8.3)$ & $5(1.4)$ & $0.044^{*}$ \\
\hline *Chi-square test considering the significance level of $5 \%$ &
\end{tabular}

With regard to where medicinal plants are acquired, most respondents report they collect them on the backyard 239 (68.1\%), and on a smaller scale, with the neighbors 45 (12.8\%), at the grocery/health food stores 42 (12.0\%), pharmacy 11 (3.1\%) and from healers $5(1.4 \%)$. These data demonstrate the influence of the economic factor in the acquisition of medicinal plants, because the fact that many of them are grown in backyards makes them accessible to much of the population.

When asked about the reason why they use medicinal plants, this proved to be related to two main issues: because they prefer medicinal plants and because of the association to the concept of natural product, that is, a product free of side effects, as 117 (33.3\%) respondents claimed to use medicinal plants because they "are not harmful to health".

The other most cited reasons for the use of medicinal plants expressed were "I like them more" 118 (33.6\%), because "I think it is more efficient to heal" 85 (24.2\%) and "it's cheaper" 43 (12.3\%).

For many elderly, the use of medicinal plants is seen as an alternative to the use of synthetic drugs, because they are considered less harmful to health, cheaper and easily acquired. Among respondents, $267(76.1 \%)$ use to ingest preparations of medicinal plants.

Regarding the indication of medicinal plants for others, 214 (61.8\%) said they indicate, perhaps because of their high level of satisfaction 254 (72.4\%) and low rate of unwanted effects 19 (5.4\%).

Regarding the form of preparation, the most often mentioned was infusion, since leaves are the part used, justifying this form of correct use.

As regards the knowledge of the investigated elderly on the therapeutic indications and parts of the plant used, it was shown that 217 (61.8\%) of respondents use to indicate the use of medicinal plants for others. Regarding the part of the plant and how the use is made, most of respondents cited the right way. Among the 15 species cited, 14 were correctly used with respect to the part of the plant (Figure 1).

Among the 14 species of plants, the mostly cited (43.9\%, $\mathrm{n}=154)$ was mint, whose leaves are used against worms, stomachache and against flu in the form of infusion.

The boldo was the second most cited plant (41.6\%, $\mathrm{n}=146)$, being mainly used for liver problems, activating the salivary secretion and gastric juice, used in cases of hypoacidity and dyspepsia. Fennel, whose fruits are used for infusion, was cited by $36.4 \%(n=128)$ of the elderly and is mainly used as tranquilizer and digestive.

The fourth most cited plant was lemongrass (33.6\%, $n=118)$. The fifth plant was chamomile (31.6\%, n=111) with calming and antispasmodic actions as cited by respondents. The sixth was leaves of guaco, cited by $23.1 \%(\mathrm{n}=81)$ of respondents. These are used for breathing problems such as colds and bronchitis, in the form of infusion. The seventh plant was Melissa (21.9\%, n=77), whose leaves are used for infusion as tranquilizer and for diarrhea. Other plants were also mentioned by the elderly, including rosemary, rue, arnica, carqueja, "espinheira santa", eggplant, chayote and elderberry, but in smaller frequency than the above mentioned ones. 


\begin{tabular}{|c|c|c|c|c|}
\hline Medicinal plant & Scientific name & Use mentioned in the literature & $\begin{array}{l}\text { Most cited uses according } \\
\text { to research participants }\end{array}$ & Plant part \\
\hline Arnica & Arnica Montana L. & Anti-inflammatory & Anti-inflammatory & Leaves \\
\hline Common Rue & Ruta graveolens $\mathrm{L}$. & Carminative, antispasmodic & Antispasmódic & Leaves \\
\hline Boldo & Peumus boldus Molina & Disorders of the liver and Stomach & Digestive, malaise & Leaves \\
\hline Carqueja & Baccharis trimera (Less) $D C$ & Diseases of the liver, stomach and intestines & Digestive & Whole plant \\
\hline Chamomile & Matricaria chamomilla $L$. & Anxiety, insomnia, dyspepsia, flatulence & Anxiolytic & Flowers \\
\hline Chayote & Sechium edule (Jacq.) S & Hypertension & High blood pressure & Leaves \\
\hline Eggplant & Solanum melongena $L$. & Hypercholesterolemia & Cholesterol reduction & Fruits \\
\hline Elderberry & Sambucus nigra $L$. & Colds, fever, rheumatism, asthma & Flus, colds & Whole plant \\
\hline $\begin{array}{l}\text { Espinheira Santa } \\
\text { (Maytenus) }\end{array}$ & $\begin{array}{l}\text { Maytenus ilicifolia Mart.ex } \\
\text { Reissek }\end{array}$ & Ulcers, heartburn, gastralgia, gastric ulcer & Ulcer, analgesic & Leaves \\
\hline Seed of anise & Foeniculum vulgare Mill & $\begin{array}{l}\text { Bronchitis, cough, digestive disorders, } \\
\text { dyspepsia, flatulence }\end{array}$ & $\begin{array}{l}\text { Flatulence, digestive } \\
\text { problems }\end{array}$ & Fruits \\
\hline Guaco & Mikania glomerata Spreng & $\begin{array}{l}\text { Prevention and treatment of asthma, } \\
\text { bronchodilating, airway antiseptic }\end{array}$ & Flu, bronchitis & Leaves \\
\hline Mentha & Mentha piperita $L$. & $\begin{array}{l}\text { Stimulant on the digestive tract, and } \\
\text { antiseptic properties }\end{array}$ & Anthelmintic, flu, digestive & Leaves \\
\hline Rosemary & Rosmarinus officinalis $L$. & Intestinal disorders & Digestive & Leaves \\
\hline Lemongrass & Cymbopogon citratus & Antispasmodic, anxiolytic and mild sedative & Anxiolytic & Leaves \\
\hline Melissa & Melissa officinalis & Antispasmodic, anxiolytic and mild sedative & Calming, diarrhea & Leaves \\
\hline
\end{tabular}

Source: Anvisa ${ }^{(6)}$

Figure 1 - Main species mentioned for medicinal purposes by the elderly and its activity according to the literature

\section{Discussion}

The study showed that women are the ones who use medicinal plants more frequently. This result is expected, as it is a fact that in several houses or even in some communities, women take on the role of caregivers, using almost exclusively medicinal plants to take care of sick family members ${ }^{(7)}$.

As for level of education and income, we highlight that respondents have mostly 3-4 years of schooling. These data show that the vast majority of herbal users have low level of secular education and this is similar to findings of another study ${ }^{(8)}$. Regarding income, about $60.0 \%$ are retired and earn one to two minimum wages, corroborating studies that show the low income population is the one that makes most use of medicinal plants. Similar data were found in a study that evaluated the use of medicinal plants by people with diabetes and hypertension treated at a clinic in Passo Fundo, Rio Grande do Sul, Brazil ${ }^{(9)}$.

The use of medicinal plants is linked to the female component of families and this corroborates studies that show women as the main holders of knowledge about the use of medicinal plants. This reminds a historical fact, as the use of medicinal herbs dates back to primitive tribes where women were in charge of extracting the active principles of plants to use them in curing diseases ${ }^{(10)}$.

When we analyzed the reason why respondents use the plants, it was reported that they believe that these "are not harmful to health", and also reported that they "prefer", or "think that they are more efficient to heal" and "are cheaper." These data are similar to those found in other studies that point as the main reason for the use of medicinal plants that they "are not harmful to health", and that people are unaware of 
the adverse reactions that can be triggered ${ }^{(11)}$.

Study participants do not associate the use of medicinal plants to the toxic effects that they can cause. However, some studies warn about the toxic potential of some medicinal plants used by the population, with the need to make cautious use and under the guidance of health professionals ${ }^{(12)}$. Professionals working in health should be concerned, providing guidance on the use of medicinal plants as well as on other therapeutic interventions that promote the improvement of the health of users, clarifying their doubts and guiding the correct use of plants ${ }^{(13)}$.

In this study, the use of two plants were cited incorrectly: the use of chamomile leaves, because it is well known and described by some authors that the active agents of this plant are concentrated in its flower buds ${ }^{(6,14)}$. The other plant was comfrey, since this plant has great potential in wound healing when applied topically and this is due to the presence of allantoin. However, participants of the study mentioned its internal use. It is emphasized that this plant has pyrrolizidine alkaloids, which are proven hepatotoxic and carcinogenic, and its use was condemned by the World Health Organization after numerous cases of death caused by cirrhosis resulting from hepatic venoocclusive disease, caused by these alkaloids ${ }^{(15)}$.

Regarding the method of preparation, respondents reported that they put the leaves of medicinal plants in water after this has initiated boiling, leaving them immersed and capped. This form of preparation is known as infusion, and these uses are consistent with the reports of the literature and are similar to other studies ${ }^{(16)}$.

Participants in the study said that they use to indicate the use of medicinal plants to others, similar data found by another study ${ }^{(13)}$. However, this sharing of knowledge is not always done the right way, as for example the indication for internal use of comfrey, the most mentioned case and one that represents risk to health.

The most cited plants were mint, boldo, fennel, lemon balm, chamomile, guaco, arnica and rosemary. When the type of plant and the citation by participants was analyzed, it became evident that their use of the plant is in line with the literature.

The mint was the most cited plant and useful for worm infections, flu and digestive problems. These therapeutic actions are confirmed by the investigated literature and are attributed mainly to essence oils containing menthol, alpha-menthone and mentofuran, substances that stimulate gastric acid secretion, intestinal contraction and facilitate the removal of gases by decreasing tone ${ }^{(17)}$.

Boldo was indicated for dyspepsia and liver problems. This action is due to the presence of alkaloids, the main one being the Boldine whose effects are backed by extensive scientific literature ${ }^{(18)}$. Fennel was cited as calming and digestive and this is in line with studies that describe these therapeutic properties as the result of the presence of essential oils and are liberated at infusion ${ }^{(18)}$.

The lemongrass cited as calming and useful for diarrhea has this use supported by a study that also mentions antibacterial, antifungal and anticarcinogenic properties ${ }^{(19)}$. Chamomile as calming and antispasmodic is also mentioned in the literature, and the form of use was the infusion of the leaves and flowers. Its main constituents are essence oils and sesquiterpene compounds such as alpha-bisabolol, which acts as antiinflammatory oil and protector of the gastric mucosa ${ }^{(12)}$.

Guaco is used as an expectorant for influenza and its action is due to the presence of coumarin (1,2-benzopyrone), triterpenes/steroids and flavonic heterosides. It acts facilitating the fluidization of the tracheobronchial exudates or it stimulates its secretion so that they can be expelled by coughing reflex ${ }^{(19)}$.

Arnica, cited mainly due its anti-inflammatory actions, has this use supported by scientific literature. Studies show the importance of sesquiterpene lactones and triterpenes present in its phytocomplex, 
as responsible for enzyme inhibition in inflammatory processes ${ }^{(20)}$. Other plants mentioned were rosemary that has stimulant actions, it is a pulmonary antiseptic and stimulant of gastric secretion, and these actions come from the presence of essential oils, saponins and tannin; then, rue with antispasmodic action; carqueja, used for liver problems; and "espinheira santa" for stomach problems ${ }^{(20)}$.

Regarding other medicinal plants cited by the elderly, rosemary, rue, arnica, carqueja and "espinheira santa" were indicated for intestinal disorders, as antispasmodic, as anti-inflammatory, for liver problems and for stomach problems, respectively. As for eggplant, chayote and elderberry, these are used to lower cholesterol, for high blood pressure, for flus and colds, respectively, and these information are coincident with the scientific literature ${ }^{(6)}$.

The limiting factor of this study was the completion at the Consortium of the North of Paraná that provides service to regional health districts of the region, but that has unique characteristics when compared to other states that provide the same service. Thus the results characterize specifically this study population and can not be generalized. This suggests that further studies should be conducted in order to have a broader view on the use of medicinal plants by the elderly, without ceasing to be useful as a guide such future actions.

\section{Conclusion}

Medicinal plants are present in the daily lives of the elderly, the most used are mint, boldo, fennel, lemon grass and chamomile. The manner and the part of the plant used reflect the popular knowledge of people about medicinal plants, highlighting their importance as therapeutic resource. New studies to assess the possibility of interactions between traditional medicines and medicinal plants are suggested.

\section{Collaborations}

Pereira ARA contributed to the design of the project, analysis and interpretation of data, and the writing of the article. Velho APM, Cortez DAG and Szerwieski LLD contributed to analysis and interpretation of data. Cortez LER contributed to the conception and project. All authors contributed to the relevant critical review of intellectual content and final approval of the version to be published.

\section{References}

1. Petrovska BB. Historical review of medicinal plants' usage. Pharmacogn Rev. 2012; 6(11):1-5.

2. Fleck ECD, Poletto R. Circulation and production of knowledge and scientific practices in southern America in the eighteenth century: an analysis of Materia medica misionera, a manuscript by Pedro Montenegro (1710). Hist Cienc Saúde Manguinhos. 2012; 19(4)1121-38.

3. Ceolin T, Heck MR, Barbieri RL, Swartz E, Muniz RM, Pilon CN. Medicinal Plants: knowledge transmission in families of ecological farmers in souther Rio Grande do Sul. Rev Esc Enferm USP. 2011; 45(1):47-54.

4. Lima SCS, Arruda GO, Renovato RD, Alvarenga MRM. Representations and uses of medicinal plants in elderly men. Rev Latino-Am Enfermagem. 2012; 20(4):778-86.

5. Kurebayashi LFS, Oguisso T, Freitas GF. Acupuncture in Brazilian Nursing Practice: ethical and legal dimensions. Acta Paul Enferm. 2009; 22(2):210-12.

6. Agência Nacional de Vigilância Sanitária. Formulário de Fitoterápicos da Farmacopeia Brasileira. Brasília: Anvisa; 2011.

7. Guimaraes GP, Nobre MSC, Portela AS. Analysis about phytotherapy as an integrating practice in the Brazilian Unified Health System (UHS). Rev Bras Pl Med. 2011; 13(4):486-91. 
8. Pires IFB, Souza AA, Feitosa MHA, Costa SM. Medicinal plants as a therapeutic option in the community Montes Claros, Minas Gerais, Brazil. Rev Bras Pl Med. 2014; 16(2 supl1):426-33.

9. Silva BQ, Hahn SR. Use of medicinal plants by individuals with Hypertension, Diabetes mellitus or dyslipidemia. R Bras Farm Hosp Serv Saúde. 2011; 2(3):36-40.

10. Singh RK, Rallen O, Padung E. Elderly Adi women of Arunachal Pradesh: "living encyclopedias" and cultural refugia in biodiversity conservation of the Eastern Himalaya, India. Environ Manage. 2013; 52(3):712-35.

11. Angelo T, Ribeiro CC. Utilização de plantas medicinais e medicamentos fitoterápicos por idosos. C\&D-Rev Eletr Fainor. [Internet]. 2014 [citado 2016 mar 20]; 7(1):18-31. Disponível em: http://srv02.fainor.com.br/revista/index.php/ memorias/article/viewFile/246/188

12. Pessoa RMC, Medeiros MTR, Riet-Correa F. Economic impact, epidemiology and control poisonous plants in Brazil. Pesq Vet Bras. 2013; 33(6):752-58.

13. Araújo KRM, Kerntopf MR, Oliveira DR, Menezes IRA, Brito Júnior FE. Plantas medicinais no tratamento de doenças respiratórias na infância: uma visão do saber popular. Rev Rene. 2012; 13(3):659-66.

14. Hartmann KS, Onofre SB. Antimicrobial activity of the essential oils of chamomile (Matricaria chamomilla L.) Saud Pesq. 2010; 3(3):279-84.
15. Sandini TM, Berto MSU, Spinosa HS. Senecio brasiliensis e alcaloides pirrolizidínicos: toxicidade em animais e na saúde humana. Biotemas. 2013; 26(2):83-92.

16. Oliveira HB, Kffuri CW, Casali VWD. Ethnopharmacological study of medicinal plants used in Rosário da Limeira, Minas Gerais, Brazil. Braz J Pharmacog. 2010; 20(2):256-60.

17. Teixeira B, Marques A, Ramos C, Batista S, Serrano $\mathrm{S}$, Matos O, et al. European pennyroyal (Mentha pulegium) from Portugal: Chemical composition of essential oil and antioxidant and antimicrobial properties of extracts and essential oil. Ind Crops Prod. 2012; 36(1):81-7.

18. Vogel H, González B, Razmilic I. Boldo (Peumus boldus) cultivated under different light conditions, soil humidity and plantation density. Ind Crops Prod. 2011; 34(2):1310-12.

19. Czelusniak KE, Brocco A, Pereira DF, Freitas GBL. Farmacobotânica, fitoquímica e farmacologia do Guaco: revisão considerando Mikania glomerata Sprengel e Mikania laevigata Schulyz Bip. ex Baker. Rev Bras Pl Med. 2012; 14(2):400-9.

20. Alfredo P, Anaruma CA, Pião ACS, João SMA, Casarotto RA. Effects of phonophoresis with Arnica montana onto acute inflammatory process in rat skeletal muscles: An experimental study. Ultrasonics. 2009; 49(4):466-71. 